Dario Budimir

DOI: https://dx.doi.org/10.21857/y26kec4ej9

Izvorni znanstveni članak

Rukopis prihvaćen za tisak: 11.12.2019.

\title{
KNJIŽEVNA RECEPCIJA KANIŽLIĆEVE SVETE ROŽALIJE
}

\begin{abstract}
Sažetak
Sveta Rožalija, panormitanska divica Antuna Kanižlića, objavljena u Beču 1780., jedno je od najpoznatijih djela hrvatske književnosti 18. stoljeća u Slavoniji. U prvome dijelu rada promotrit će se recepcija toga djela u kronološkome slijedu. Nakon raščlambe prvih kritika iz druge polovine 19. stoljeća objavljenih većinom u listovima katoličke orijentacije, promotrit će se recepcija Svete Rožalije u 20. stoljeću - najprije u onih autora s početka stoljeća (Tomić, Prohaska, Vodnik, Fancev), zatim iz sredine stoljeća (Kombol, Matić), a onda i iz druge polovine 20. stoljeća (Georgijević, Belić, Peić, Jelčić). Od 1990., nakon osamostaljenja Republike Hrvatske, raste interes istraživača za stariju hrvatsku književnost, pa tako i za Svetu Rožaliju, ali najviše u okviru istraživanja hrvatske barokne književnosti (Kravar, Pavličić, Fališevac, Tatarin). Početkom 21. stoljeća tim se djelom bavi nekoliko autorica (Pšihistal, Marković, Šundalić) iščitavajući nove aspekte djela ili analizirajući rad nekoga od ranijih teoretičara (Crnjac).
\end{abstract}

Ključne riječi: Antun Kanižlić; Sveta Rožalija; barok; recepcija.

$* * * * * * * * * * * *$

Sveta Rožalija, panormitanska divica jedno je od najpoznatijih djela hrvatske književnosti 18. stoljeća u Slavoniji. Napisao ju je požeški isusovac Antun Kanižlić (1699. - 1777.), koji je bio ugledni profesor i nadzornik isusovačkih škola, pučki misionar i propovjednik, autor molitvenika, katekizama i jedne teološke rasprave. Rožalija je vjerojatno nastala 1759. (usp. Miljenko Belićn ), a objavljena je u Beču 1780., uz potporu budućega đakovačkog biskupa Antuna Mandića. Kanižlić donosi zaokruženu priču o svetici Rozaliji iz Palerma sa Sicilije iz 12. stoljeća koja je služila Bogu u potpunoj povučenosti od svijeta te koja je, nakon što je u zrcalu ugledala Krista, donijela radikalnu odluku da napusti vjerenika i roditeljski dom. Rožalija ostaje vjerna Gospodinu unatoč iskušenjima i napastima provodeći dane u postu i molitvi, iako u

1 Miljenko Belić „Tko je napisao ‘Obilato duhovno mliko"““, „Vrela i prinosi“, Zagreb, 13, 1982., str. 161 
Kanižlićevu djelu taj prikaz Rožalijine molitve u većoj mjeri izostaje (o tome više u tekstu Zlate Šundalić $)$.

Slutnju o mogućoj recepciji djela iznio je već sam Kanižlić u prvome dijelu Rožalije, u poduljem opisu borbe između sove (koja predstavlja njegovo djelo) i ostalih ptica (kritičara), što znači da je Kanižlić bio itekako svjestan onih kojima se njegovo književno djelo neće svidjeti. Ipak, u hrvatskoj književnosti na prijelazu iz 18. u 19. stoljeće Sveta Rožalija imala je velika zagovornika u liku klasicista Matije Petra Katančića, koji tvrdi da je Kanižlićevo pisanje uz bok najboljim europskim pjesnicima smatrajući ga „u prozi ravnim Ciceronu, a u pjesmi Ovidiju“3. Tijekom druge polovine 19. stoljeća o Kanižliću se većinom pisalo u listovima kršćanske orijentacije (Katolički list, Zagrebački katolički list), s pretežitim naglaskom na svjetonazorsko određenje tekstova. S kraja je 19. stoljeća i opažanje Ivana Scherzera ${ }^{4}$, koji je tvrdio kako je Kanižlić napisao spjev vođen dvjema legendama, onoj o sv. Rožaliji iz Palerma i o sv. Rožaliji Limskoj (iz Lime u Peruu). Na samom izmaku 19. stoljeća Đuro Šurmin zaključuje: ,'Rožalija' je napisana prema Đorđićevim 'Uzdasima Mandalijene pokornice', samo je drugi predmet pjesmi i drugo narječje, a gdje što je u Kanižlića i narodnog duha. Vrijednost je djela i u tom, što se njim pokazuje sveza između dubrovačkih isusovaca i onih u Slavoniji." ${ }^{5}$

Od početka 20. stoljeća mijenjala se i recepcija djela, čije su težište, ali i najveća razilaženja, najčešće bili u periodizacijskim i žanrovskim odrednicama jer su prema književno-stilskim osobinama teksta teoretičari zaključili kako je Rožalija pretežno barokno djelo, ali uz moguće utjecaje klasicizma, rokokoa i prosvjetiteljstva, dok se žanrovski smatra religioznom poemom, ali i epom i epistolarnim oblikom.

Tezu da je Rožalija barokni tekst iznosi još 1907. Branko Vodnik6. Svetu Rožaliju ističe kao jedini primjer isusovačkoga baroka u Slavoniji. Glavne su Vodnikove teze kako u djelu postoji: izrazita barokna poetika i figuracija te stilska i sadržajna sličnost s Đurđevićevim Uzdasima Mandalijene pokornice i Gundulićevim Suzama sina razmetnoga, npr. usporedni opis zavodnice iz Gundulićevih Suza i alegorije bludnosti iz Rožalije s kosom poput zmija; iskazi o prolaznosti vremena, zajednički provedbeni motiv o ptici feniks, motiv motrenja Kristovih rana u Rožaliji i Mandalijeni pokornici, sličnost u leksiku. Međutim, naglašava i razlike. Dok su dubrovački tekstovi sažetiji,

2 Zlata Šundalić „Molitva u Kanižlićevu stvaralaštvu“, u: zbornik Ključevi raja: hrvatski knjižeoni barok i slavonska književnost 18. st., Osijek - Požega, 1993., prir. Julijana Matanović.

3 Matija Petar Katančić Knjižica o ilirskom pjesništvu izvedena po zakonima estetike. Izdavački centar revija, Radničko sveučilište „Božidar Maslarić“, Osijek, 1984.

4 Ivan Scherzer „A. Kanižlića Sv. Rozalija i Kamen pravi smutnje velike“, Nastavni vjesnik, III. Zagreb, 1895., str. 201-217.

5 Đuro Šurmin Povijest književnosti hrvatske i srpske, Kugli i Deutsch, Zagreb, 1898.

6 Branko Vodnik Slavonska knjižeonost u 18. stoljeću, Naklada knjižare M. Breyera, Zagreb, 1907. (pretiskano u Slavonica, Vinkovci, 1994.), str. 9-22. 
Rožalija je razvučenija i puna digresija. Jedan od Vodnikovih navoda jest kako je Kanižlić „,epigon baroka, jedan od zakašnjelih pjesnika kakvih ima u svim razdobljima", a na tu će se tezu referirati mnogi kasniji teoretičari. Valja naglasiti kako prvi na taj način o Kanižliću ipak nije pisao Vodnik nego Dragutin Prohaska u svojoj doktorskoj disertaciji Ignjat Đorđić i Antun Kanižlić. Studija o baroku u našoj knjižeonostī, što dokazuje Ines Srdoč-Konestra ${ }^{8}$ navodeći kako je Vodniku Prohaskina rasprava bila poznata iz rukopisa. Jedna od Prohaskinih teza jest to da se zbog svojega narodnoga izraza Rožalija udaljuje od tipičnosti baroknoga djela. Pučke elemente kasnije prepoznaje i Tomo Matić, koji uspoređuje Kanižlićeve liturgijske i pučke pjesme te uviđa da su najuspjelije one pjesme koje su posvećene duhovnoj ljubavi, a upravo je Rožalija cijelo takvo djelo. Matić zaključuje: „Kanižliću se ne može poreći da je u 'Rožaliji' stvorio pjesničko djelo, s kojim se po umjetničkoj izradi ne mogu takmiti književna djela što ih je hrvatska književnost dala Slavoniji prije Preporoda. ${ }^{.10}$

$\mathrm{S}$ druge strane, u svojoj doktorskoj disertaciji Barok i rokoko u djelu Antuna Kanižlića ${ }^{11}$ Matko Peić osporava tezu da Kanižlićeva Rožalija pripada isključivo baroku ističući njezine elemente rokokoa i predromantike te afirmirajući samoga Kanižlića kao važnog pisca. O rokokou u Kanižlića najprije je pisao slavist Andreas Angyal ${ }^{12}$, a Matko Peić naglašava: „baroknog su podrijetla u tekstu stilske figure (metafora, metonimija, perifraza, antiteza, parabola, anadiploza, anafora id.), tema prolaznosti ljepote i života te motiv tame, noći i smrti“. Međutim, Peić uz rokoko veže osjećaj optimizma, humor i smijeh, vivifikaciju fiziologije, motiv svjetlosti, portretizam, detaljne opise haljine i frizure, afirmaciju prirode i brojne deminutive ${ }^{13}$. Istodobno iznosi i tezu o gledanju govoreći da barokni pjesnik promatra „iz zone unutarnjega oka“, a pjesnik rokokoa iz „vanjskoga oka“. Peić zaključuje da je Rožalija jedinstven primjer rokokoa te je „himna Prirodi i sunčevoj svjetlosti, zemlji koja rađa biljem, životinjama, pticama, potoku koji rađa svježinu i žubor" ${ }^{\prime 14}$. Tonko Maroević naglasio je da ta Peićeva rasprava nije napisana suho i dosadno nego je „strastvena tematska

\footnotetext{
7 Dragutin Prohaska Ignjat Đorđić i Antun Kanižlić. Studija o baroku u našoj književnosti, Zagreb, 1909.

8 Ines Srdoč-Konestra „Prohaskina 'Studija o baroku u našoj književnosti'“, u: Zbornik o Dragutinu Prohaski, književnom povjesničaru i književnom kritičaru, Zbornik radova sa znanstvenoga skupa, Osijek, 16. i 17. svibnja 2002., Zagreb, 2003.

9 Tomo Matić „Život i rad Antuna Kanižlića“, u: Pjesme Antuna Kanižlića, Antuna Ivanošića i Matije Petra Katančića. Stari pisci hrvatski, 26. Zagreb, 1940., str. XIII-XLI.

10 Antun Kanižlić, Sveta Rožalija, Stari pisci hrvatski, knjiga XVI, priredio Tomo Matić, JAZU, Zagreb, 1940.

11 Matko Peić Barok i rokoko u djelu Antuna Kanižlića (1699.-1777.), Rad JAZU, Zagreb, 1972.

12 Andreas Angyal Die slawische Barockwelt, Leipizig, 1961.

13 Mirna Sindičić Sabljo „Epistolarni oblik Kanižlićeve Svete Rožalije“ u: Komparativna povijest hrvatske književnosti, Zbornik radova XVII. Poema u hrvatskoj književnosti: problem kontinuiteta, Split-Zagreb, 2015.

14 Matko Peić Slavonija - književnost, Izdavački centar "Revija“, Radničko svučilište „Božidar Maslarić" Osijek, 1984.
} 
inventura i lucidna stilistička analiza“15. Početkom 90-ih godina 20. stoljeća Zoranu se Kravaru ta hipoteza „o rokokou, čini vrijednom razmišljanja“16, dok u svojemu drugom tekstu, Predmeti i znakovi u tematskome svijetu Svete Rožalije, također piše o alegorijskim odrednicama djela. Da je Peić odabrao dobar intepretacijski ključ, u većoj se mjeri slaže i Miljenko Belić ${ }^{17}$ te Ružica Pšihistal. ${ }^{18}$

Josip Bratulić navodi da su ranije Kanižlićeve pjesme samo priprema za „veliko djelo hrvatske barokne književnosti“19. Bratulić se slaže s Vodnikom i nizom drugih autora da je on barokni pisac koji nasljeduje hrvatsku religioznu poemu Bunićeva, Đurđevićeva i Gundulićeva tipa. Međutim, naglašava da su snažno prisutni i klasicistički elementi koji katkada i pretežu, a tomu u prilog ide i Katančićev osvrt na Kanižlićev rad. Bratulić navodi da u Rožaliji supostoje dvije poetike: barokna i klasicistička, objašnjavajući razliku u figuraciji, tj. na koji je način klasicistička personifikacija zamijenila tipičnu baroknu alegoriju. Personifikacijom se Kanižlić obilato služi u svemu, u prikazu kreposti, vremena, mjeseci, sunca, satova. Bratulić ističe i ogledalo kao važan element toga teksta (ono ima istu funkciju koju je u renesansnoj i baroknoj poeziji imao san) jer je ogledalo glavni prostor zbivanja. Rožalija se pred njim kiti i uređuje, u njemu se ukaže Ljubav Božja, u njemu vidi Isusa, a u istome ogledalu spoznaje i svoje grijehe. Klasicističke elemente uočava i Pavao Pavličić navodeći da je Kanižlićev „minuciozni opis pojava iz predmeta svijeta (je) karakterističan upravo za klasičnu i klasicističku književnosti ${ }^{\prime 20}$. Za razliku od Bratulića, za Pavličića je upravo alegorija klasicističko, a ne barokno obilježje. S druge strane, Zoran Kravar, u već spomenutom djelu, odbacuje klasicističke utjecaje u Rožaliji.

Milovan Tatarin, služeći se Greimasovim semiotičkim četverokutom u Rožaliji (kao i u drugim baroknim plačevima), pronalazi os grešnost - krepost koja, kada se proširi u četverokut, postaje: grešnost - krepost - odsutnost kreposti - odsutnost grešnosti te ističe odgojne epizode koje u ostalim plačevima izostaju. On tako u Rožaliji prepoznaje da je to „karakterističan prosvjetiteljski tekst, sa specifičnom zadaćom i nakanom. Ipak, ona ne pripada tipu 'reljkovićevskog prosvjetiteljstva', već jednoj drugoj vrsti koja bi se uvjetno mogla imenovati kao 'estetizirano isusovačko prosvjetiteljstvo'.“21

\footnotetext{
15 Matko Peić 1923.-1999., HAZU, Spomenica preminulim akademicima sv. 114, Zagreb, 2003., ur. Dubravko Jelčić, str. 17 (Tonko Marović „Matko Peić“).

16 Zoran Kravar Nakon godine MDC, Matica hrvatska, Dubrovnik, 1993.

17 Miljenko Belić „Antun Kanižlić 1699.-1777. Uz dvjestagodišnjicu njegove smrti“ - „Obnovljeni život“, br. 32, 1977.

18 Ružica Pšihistal Satir nije divlji čovik, Ogranak Matice hrvatske u Osijeku, 2011.

19 Antun Kanižlić Sveta Rožalija, „Privlačica“, Vinkovci, 1994., predgovor Josip Bratulić, str. 129-138.

20 Pavao Pavličić Rasprave o hrvatskoj baroknoj književnosti, Čakavski sabor, Split, 1979., str. 57-58.

21 Milovan Tatarin „Struktura Svete Rožalije Antuna Kanižlića u optici Greimasovog semiotičkog četverokuta", u: zbornik Ključevi raja: hrvatski knjiežvni barok i slavnoska književnost 18. st., Osijek - Požega, 1993., prir. Julijana Matanović.
} 
U žanrovskome smislu Rožalija se najčešće određuje kao religiozna poema (usp. Milovan Tatarin ${ }^{22}$, Josip Bratulić́ ${ }^{23}$, Zlata Šundalićc ${ }^{24}$ ). Djelomično se razlikuje Dunja Fališevac, koja tvrdi da je riječ o „religioznoj epici, sa sekundarnim generičkim obilježjima barokne poeme, svetačkih legendi i srednjovjekovnih alegorijsko-religioznih žanrova“ ${ }^{\prime 25}$.

Osobit zamah u proučavanju starije hrvatske književnosti dogodio se nakon 1990., s jedne strane zbog osamostaljenja Republike Hrvatske, a s druge zbog čitanja tekstova na nov način na temelju novih pravaca u književnoj metodologiji. Zbog kratkoće i preglednosti ovog rada, spomenut će se neki od tekstova. Tako je Mirna Sindičić Sabljo pisala o epistolarnome obliku Svete Rožalije ističući kako „podrijetlo tog oblika ne bi trebalo tražiti u epistolarnoj književnosti 17. i 18. stoljeća već u kulturi pisanja pisama u svakodnevnom životu u Europi toga vremena ili u žanru poslanice iz starije hrvatske književnosti“26. Milovan Tatarin ${ }^{27}$ analizira strukturu i izraz Kanižlićevih stihova. Njegova je teza da je funkcija dvostrukorimovanoga dvanaesterca u djelu narativna i estetska jer djelu daje literarnu upakiranost, povezanu s tradicijom i klasičnošću, a povremenom upotrebom sestina i katrena šalje važne poruke koje čitatelj valja upamtiti. Kanižlić se služi i osmercima, desetercima i sedmercima te anakreontskim motivima. Branka Brlenić-Vujić2 ${ }^{28}$ analizirala je model pučkoga smijeha, a jezični aspekt Svete Rožalije proučavali su Josip Vončina ${ }^{29}$, Ljiljana Kolenic ${ }^{30}$ i Vlasta Rišner ${ }^{31}$. Dunja Fališevac ističe da se Rožalija razlikuje od drugih dubrovačkih poema zbog toga što izostaje dvoglasnost jer je pripovjedač sama Rožalija, a uočava se i „upletenost mnogih lica u djelo, razni opisi vanjskoga svijeta, dvora u Palermu ili kuge, stalna vremenska distanca prema onome što se dogodilo, a ne svevremenost te nizanje opisa o raznim lokalitetima“"32. Pregršt Kanižlićevih molitvenika sustavno je istražila Zlata Šundalić, koja zaključuje da je upravo molitvenicima, kao posebnom vrstom pučke književnosti, započeo piščev rad. Ti su mo-

22 Milovan Tatarin „Kanižlićeva Sveta Rožalija i metametrički aspekti stiha i oblika“, Umjetnost riječi, 39 (1995), str. 105-125.

23 Isto.

24 Zlata Šundalić "Molitva u Kanižlićevom stvaralaštvu“, u: Kroz slavonske libarice. Rasprave o nabožnoj književnosti u Slavoniji, Ogranak Matice hrvatske Osijek, 2005., str. 143.

25 Dunja Fališevac Kaliopin vrt II. Studije o poetičkim i ideološkim aspektima hrvatske epike, Književni krug, Split, 2003., str. 99.

26 Sindičić Sabljo, isto.

27 Tatarin, isto.

28 Branka Brlenić-Vujić „Model pučkog smijeha u Kanižlićevoj Svetoj Rožaliji i slavonska književnost u 18. stoljeća“, u: Ključevi raja: hrvatski književni barok i slavonska književnost 18. stoljeća, str. 233-252.

29 Josip Vončina Jezik Antuna Kanižlića, JAZU, Zagreb, 1975.

30 Ljiljana Kolenić Pogled u frazeologiju Kanižlićeve „Rožalije“. Filologija, 20-21 (1992.-93.), str. 215-219.

31 Vlasta Rišner „Iskazivanje vremena u Svetoj Rožaliji i Bogolyubnosti molitvenoj Antuna Kanižlića“, u: Ključevi raja: hrvatski književni barok i slavonska književnost 18. stoljeća, str. 311-328.

32 Hrvatski književni barok, ur. Dunja Fališevac (članak „Hrvatska epika u doba baroka“), str. 155-198. 
litvenici u prvoj fazi bili više u sferi umjetničke književnosti te su manje udovoljavali puku, ali kasnije su djela bliža pučkom izrazu, ,što potvrđuje pet izdanja Bogoslovice i pet izdanja Bogoljubosti molitvene ${ }^{u 33}$. Kanižlićevu liturgijsku liriku Zoran Kravar smatra uspješnijima od same Rožalije, a jedan od razloga jest i kratkoća u kojoj barokni izraz postaje uspješniji i sugestivniji. U novije vrijeme nastaju i tekstovi u kojima se posredno analizira i neki od aspekata Kanižlićeve Rožalije, pa tako Maja Crnjac ${ }^{34} \mathrm{u}$ analizi književnoga rada Matka Peića najveći dio posvećuje upravo Kanižliću, a slično čini i Dina Markovićn ${ }^{35}$. Anela Mateljak Popić i Zlata Šundalić istražile su jeku kao rubni motiv u starijoj hrvatskoj književnosti, a u Rožaliji je ta jeka varljiva i predstavlja opsjenu te odmaže liku, što nije bio slučaj u nekim drugim starijim tekstovima.

Sve nas to navodi na zaključak kako se Kanižlićevoj Svetoj Rožaliji pristupalo iz različitih interpretacijskih ključeva i da je neosporno riječ o jedinstvenome tekstu u hrvatskoj književnosti koji će i u budućnosti, zbog svoje slojevitosti, predstavljati velik izazov istraživačima. Nakraju, ta fascinantna priča o potpunom darovanju svojega života Bogu pomaže nam i danas bolje razumjeti one djevojke i žene koje odabiru posvećeni način života, u strogoj klauzuri karmelićanki, klarisa, benediktinki, kartuzijanki, cistercitkinja, sestara Marijina Pohoda i drugih monahinja koje sve što imaju stavljaju na kartu vječnoga života, dok neke od njih čine istovjetan korak Rožaliji i postaju pustinjakinje (dovoljno je sjetiti se nekadašnje glumice Edite Majić, koja je najprije stupila u najstroži Karmel u Avili, a nedavno se povukla u pustinju). U odnosu na duh vremena u kojemu živimo, takav korak postaje još hrabriji i neobičniji nego u Rozalijino ili Kanižlićevo doba i postaje znakom koji nas sve ostavlja u dubokoj tišini pred velikom tajnom ljudske duše i Boga.

\footnotetext{
33 Zlata Šundalić Studenac nebeski, Književni krug, Split, 2003., str. 272-303, 327-365, 431-448.

34 Maja Crnjac „Književnopovijesni rad Matka Peića“ - „Radovi Zavoda za znanstveni i umjetnički rad u Požegi“, 3 (2014), str. 17-24.

35 Dina Marković Peićev barok i rokoko, Hrvatsko filološko društvo, Rijeka, 2000.
} 


\section{Literary Reception of Sveta Rožalija by Antun Kanižlić}

\section{Summary}

Sveta Rožalija, panormitanska divica by Antun Kanižlić, published in Vienna in 1780, is one of the best-known works of Croatian literature of the $18^{\text {th }}$ century in Slavonia. The first part of this paper explores the reception of this work in chronological order. After analysing the first critical writings from the second half of the $19^{\text {th }}$ century, mainly published in Catholic-oriented newspapers, this paper will focus on the reception of Sveta Rožalija in the $20^{\text {th }}$ century. The thesis first examines how the work was received among authors at the beginning of the $20^{\text {th }}$ century (Tomić, Prohaska, Vodnik, Fancev), then around the midcentury (Kombol, Matić), and finally, it focuses on the reception of the work in the second half of the $20^{\text {th }}$ century (Georgijević, Belić, Peić, Jelčić). Since 1990, after the Republic of Croatia had gained independence, there has been a growing interest in the research related to older Croatian literary works - and consequently to Sveta Rožalija too, mainly as a part of Croatian Baroque literature (Kravar, Pavličić, Fališevac, Tatarin). At the beginning of the $21^{\text {st }}$ century, there are several female authors studying this work (Pšihistal, Marković, Šundalić) who are either discovering new aspects to it or analysing the work of some of the earlier theorists (Crnjac).

Keywords: Antun Kanižlić; Sveta Rožalija; Baroque; reception.

Dario Budimir, prof.

Klasična gimnazija

Križanićeva 4a, 10000 Zagreb

dario.budimir5@gmail.com 
